\title{
Large-scale analysis of perceptual odor data
}

\author{
Benjamin Auffarth \\ From 1st International Workshop on Odor Spaces \\ Hannover, Germany. 4-7 September 2013
}

It is a general problem in sensory processing to understand which aspect of the sensory input is relevant to perception. In olfaction, because of the high-dimensionality, and the difficulty in describing smells [1]. One of the core questions in olfaction is therefore the so-called structureodor relationships. A deeper understanding of olfaction should involve aspects of natural stimulus statistics, odorant properties, physiological responses, evolution, odor perception, and behavioral relevance. As a step towards computational analyses in this direction, I accumulated a database consisting of several hundred perceptual descriptors for several thousand odors by merging data from different publicly available sources. Preliminary results from this dataset based on unsupervised and unsupervised methods are presented here. These preliminary results could give a better idea of the dimensionality of the odor space, and of how to approach studies of structure-odor relationships.

Acknowledgement: participation to this meeting was supported by an ECRO Travel Grant.

Published: 16 April 2014

\section{Reference}

1. Auffarth B: Understanding smell-the olfactory stimulus problem. Neurosci Biobehav Rev 2013, 37:1667-1679.

Submit your next manuscript to BioMed Central and take full advantage of:

- Convenient online submission

- Thorough peer review

- No space constraints or color figure charges

- Immediate publication on acceptance

- Inclusion in PubMed, CAS, Scopus and Google Scholar

- Research which is freely available for redistribution 